\title{
C $\mathbf{P} \mathbf{C}$
}

（昭和38年 7 月 6 日関西医科大学学術集祁会記鈞）

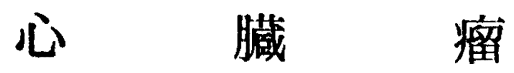

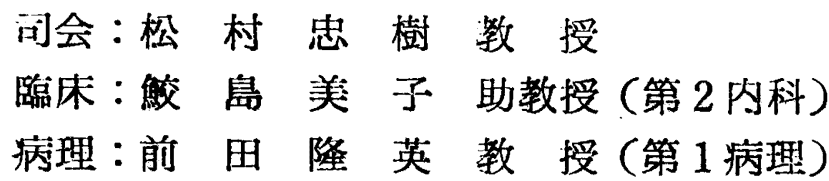

\section{碚床病歴及び所見}

症

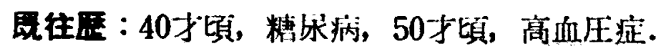

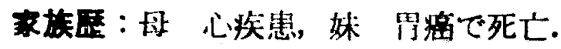

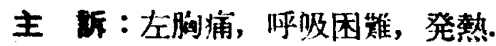

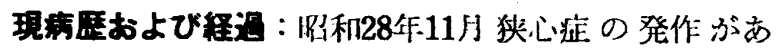

り，医治橑空うけた。

昭和29年:8月20日, 资然左局に放散与る左胸部の激哺 をきたし，冷汗，呼吸困難をともない某医の治療をう け，一応寞解し，8月31日当科を訪れた。 その後外来治 凉を行い，比較的安静な生活をむくつていたが，昭和30 年, 31年, 34年に各 1 回, 35年, 36年に洛 2 回同様の胸 痛発作をきたし，度々心不全に宿つた。て元間昭和 35 年 3 月 1 日胸桷発作につゔき心缄喘息を招来, 15日閭入院 加集した．36年12月初旬より胸痛の小発作が頻発し, 顔 面，下肢:渚明な浮腫が比現，37年 6 月 16 日朝より呼吸

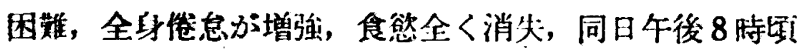
$39^{\circ} \mathrm{C}$ の発熱をきたし，意識注次第に混濁，種々加橑した ふ，解熱の敞なく，6月17日午後 5 時自宅において死亡 した.

\section{现症}

清和29年 8 月31日（初洛時）。

体格, 栄䈍中等, チフノーゼなく, 呼吸数21, 脈拍 90 , 整,

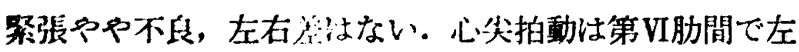
铛骨中線より 2 横指外に，また第 V胁閒で鎖骨中線より 1 横指外に心尖拍動上りやや弱い拍動を触知，心濁音界 山右界环中線，上界第正肋骨，左界法心尖拍動部に一致

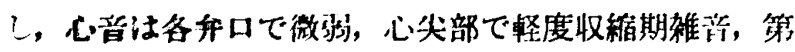

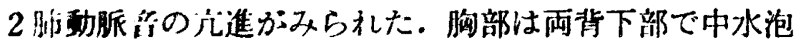
要を噹取し，腹部は朋 1 横指触知したが，压痛なく，腹 水畹激なく、下肢に軽度の浮腫を諗めた。

略和35年 3 月 1 月（入院時）。

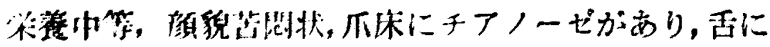

灰白他の舌苔を諗む. 咽頙軽度発亦, 呼吸㳀薄で起坐呼吸 を行い，脈拍120，整，緊張不良，心尖拍動，心渴音界，

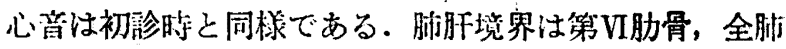
野に乾性亏音を聴取, 旰は右乳線上 2 横指触知, 压痛な く, 腹水の貯溜もない。下肢腱反射は減退，異常反射な く, 浮埂も羿められ沈い。

眧和37年. 6 月 16 日(死亡前)。

栄養衰え，顔貌苦悶状，口唇，チデノーゼがあり，意 激やや混濁, 瞳孔左右同大, 正円, 対光反応遅延, 舌は 灰白色の厚い舌苔を被むり，咽頭発赤あり，呼吸浅薄，脈 拍88, 整, 緊張微弱, 心臟部理学的所見は初䩕時及び35 年の入院時に同じ．胸部は左右両下肺野に湿性ラ音を， 右上肺野に乾性ラ音を聴取, 腹部は陥沿し，肝は右季肋 下乳線上 3 横指触知，やや硬く，軽度の生痛があり， 朝，腎は触知せず，腹水なく，莖静脈の怒張をみとめ る。腱反射消失，下肢に著明な浮腫があつた。

\section{臨床検查欺錄}

(1) 初䪾時胸部レントゲン所見 (

(2) 各時期の血液打よびその生化器検查所見（第 1 表 A及びB).

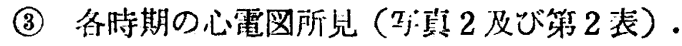

\section{討 䎐}

松忖：以上の様な現病歴でありますが，外来の検査の ため検査成縉として不充分であると思われます。一般の 方からの質問を後にして指導的な立場の先生から御意見 を何います，松田教授如何ですか。

松旧：このレ線像では左心室が大さいか，或は肺に陰 影があるかどうかを先ゔ考えます。もし，心臟が肥大し ていると与れば心筋が弱丈り，膨隆している，即ち心筋 梗塞があつてその部が弱くなつている場合で，もし肺に 所見がある場命は仿度を変えてとれ代よいが，肺野のも

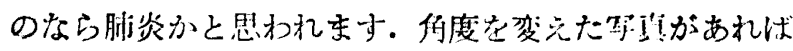


写真 1 胸部レントゲン军真
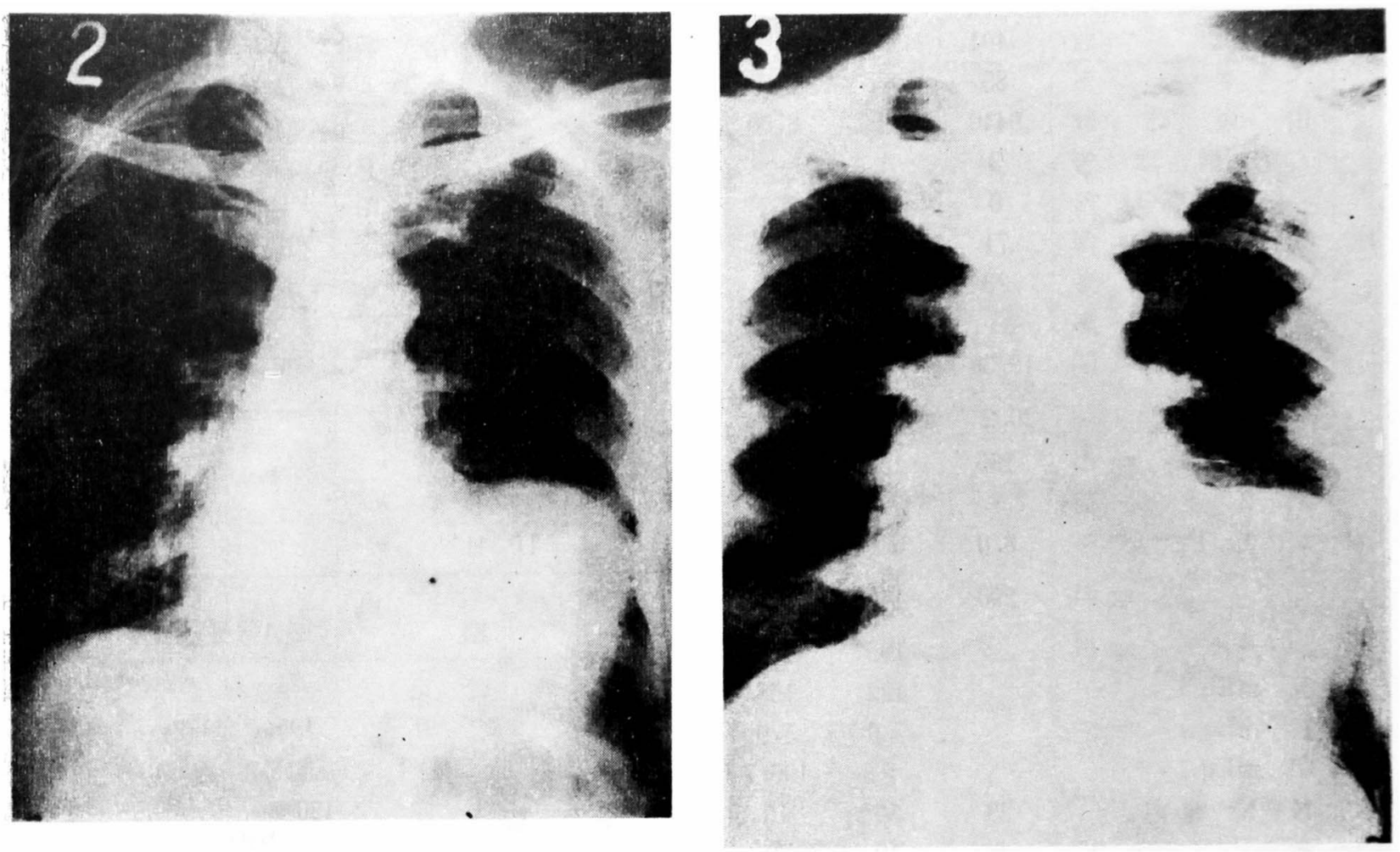

前 後 面

\section{2 重撮影}

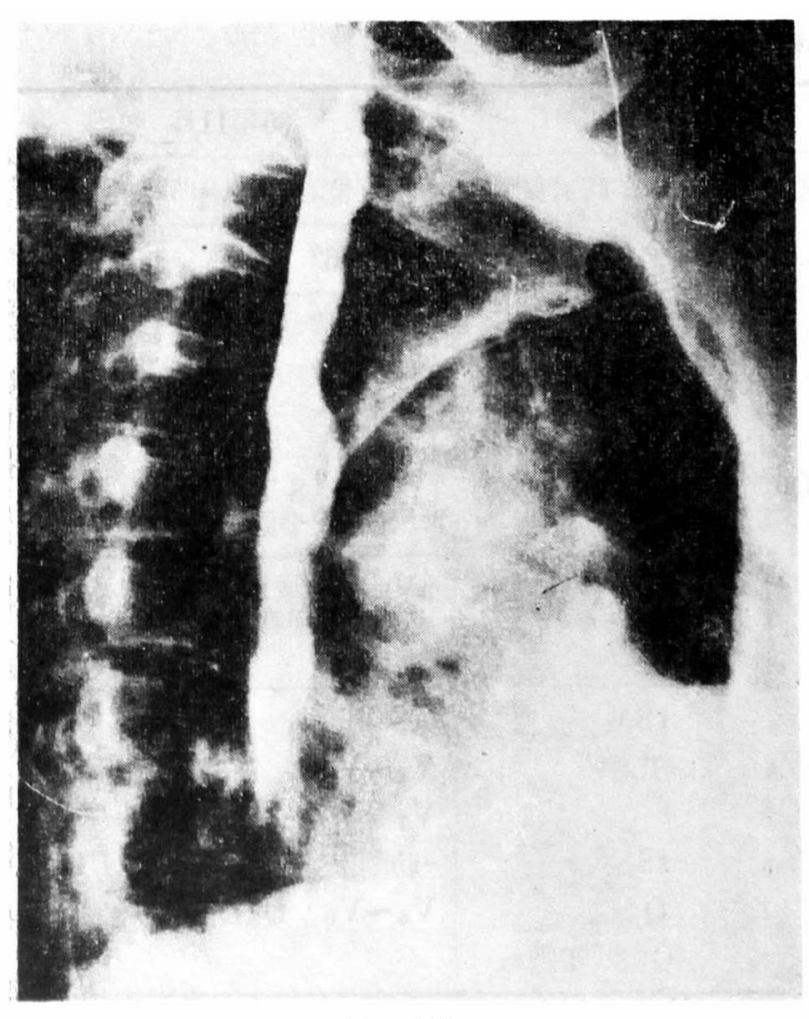

第 1 斜位

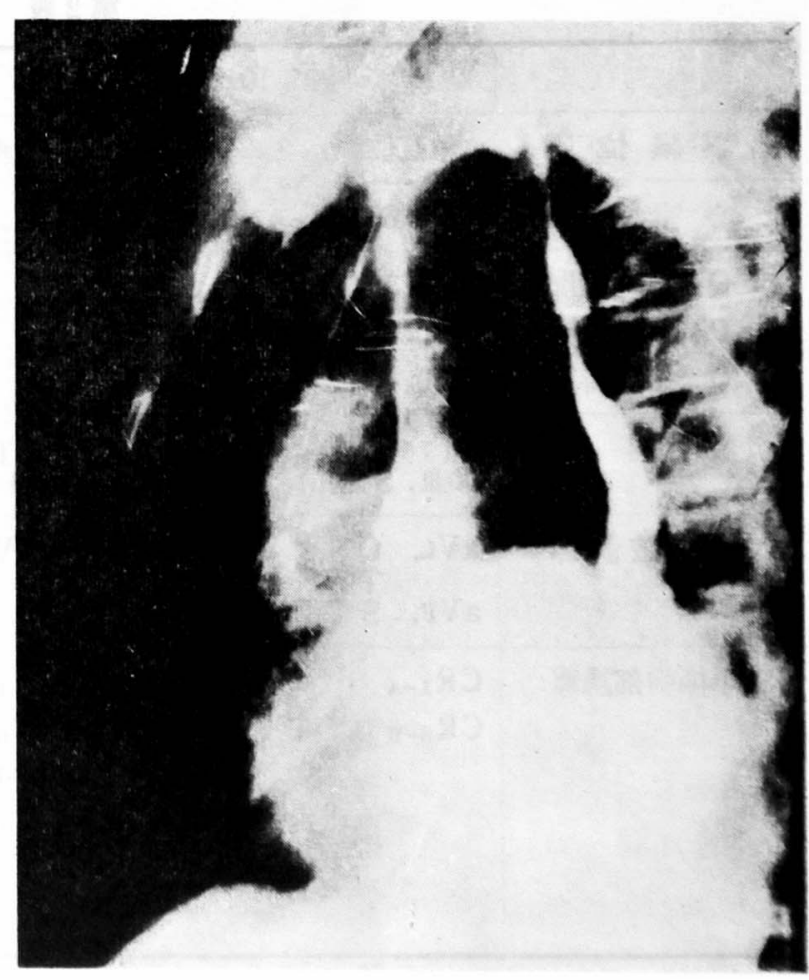

第 2 斜位 
第 1 表 $\mathrm{A}$

29 年 10 月 35 年 3 月 37 年 5 月

\begin{tabular}{|c|c|c|c|c|}
\hline \multirow[b]{3}{*}{ 血 } & 赤 血 球 数 & 401 & 400 & \multirow{10}{*}{8700} \\
\hline & へモグロビン \% & 85 & 85 & \\
\hline & 白 血 球 数 & 9440 & 8200 & \\
\hline & 好 酸 球 96 & 3 & 1 & \\
\hline H'X & 好塩基球 $\%$ & $\mathbf{0}$ & 0 & \\
\hline $\bar{H}$ & 好 中 球 $9 \%$ & 71 & 75 & \\
\hline \multirow[t]{4}{*}{ 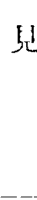 } & 洲.巴球 96 & 23 & 33 & \\
\hline & 単 & 3 & 1 & \\
\hline & 凝 固 㭙 閣 & $19^{\prime} 30^{\prime \prime}$ & & \\
\hline & プロトロンビン時間 & $20.2^{\prime \prime}$ & $20.0^{\prime \prime}$ & \\
\hline \multirow{10}{*}{$\begin{array}{l}\text { 血 } \\
\text { 售 } \\
\text { 花 } \\
\text { 学 } \\
\text { 的 } \\
\text { 荃 }\end{array}$} & 血鹤(空腹時) mg/dl & 155 & 168 & \\
\hline & 榶 2 重 侣 荷 & $(+)$ & $(+)$ & \\
\hline & 粉 蛋 白量 \% & 8.0 & 6.8 & 6.8 \\
\hline & $\begin{array}{l}コ レ ス テ \\
\square-ル / \mathrm{dl}\end{array}$ & 290 & 140 & 242 \\
\hline & エステル型 & & 105 & 159 \\
\hline & $\mathbf{N} \quad \mathrm{mEq} / \mathrm{l}$ & & 122 & 158 \\
\hline & $\mathrm{K} \mathrm{mEq} / \mathrm{l}$ & & 7.0 & 5.9 \\
\hline & $\mathrm{Cl} \mathrm{mEq} / 1$ & & & 106. 7 \\
\hline & N P N mg dl & 23 & 50 & 16 \\
\hline & 沈 $1^{\circ}$ & 5 & 10 & 70 \\
\hline
\end{tabular}

第 1 㤗 B

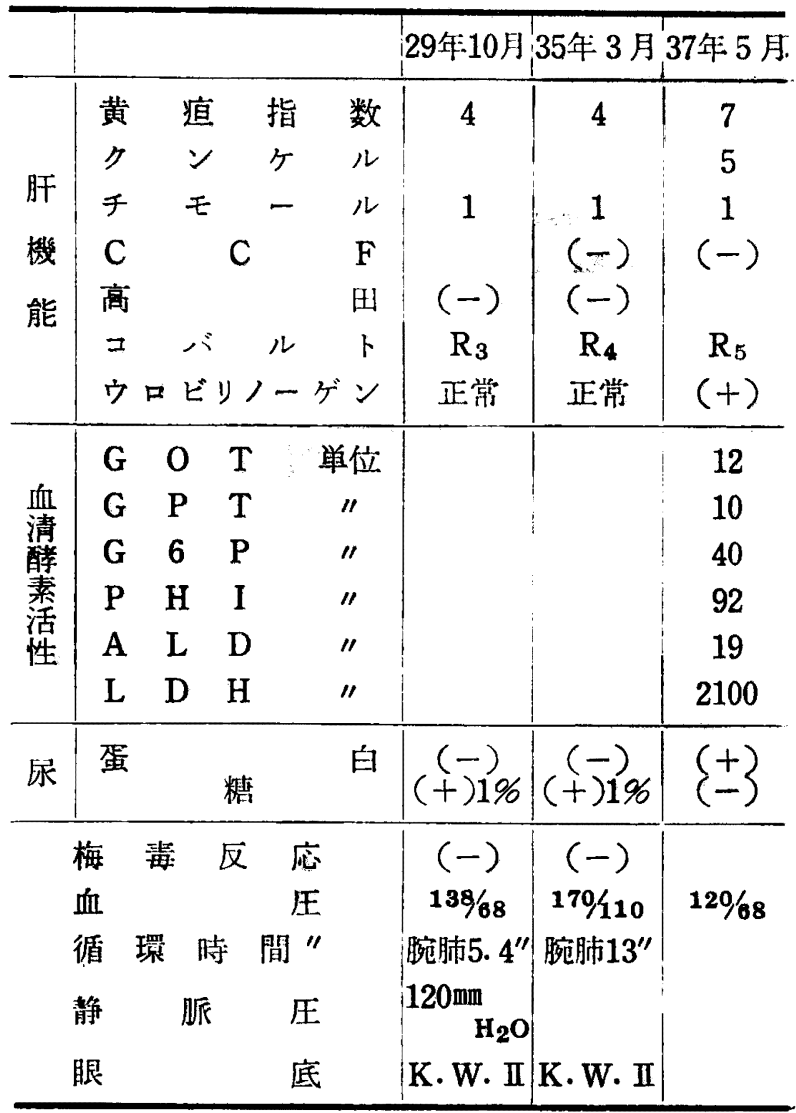

第 2 表 心园所胃

\begin{tabular}{|c|c|c|c|c|c|c|}
\hline \multirow[b]{2}{*}{ 心荿位置 } & \multicolumn{2}{|c|}{ 29年10月 } & \multicolumn{2}{|c|}{ 32年10月 } & \multicolumn{2}{|c|}{ 36年11月 } \\
\hline & 垂直位心 & 時計趈転 & 垂直位心 & 時計廻転 & 垂直位心 & 時計趈転 \\
\hline 心室 循 期 & $0.68^{\prime \prime}$ & 整 & $0.75^{\prime \prime}$ & 整 & $0.76^{\prime \prime}$ & 整 \\
\hline QRS 時間 & $0.10^{\prime \prime}$ & & \multicolumn{2}{|l|}{$0.10^{\prime \prime}$} & \multicolumn{2}{|l|}{$0.11^{\prime \prime}$} \\
\hline P $\quad \mathbf{Q}$ 時間 & $0.17^{\prime \prime}$ & & \multicolumn{2}{|l|}{$0.10^{\prime \prime}$} & \multicolumn{2}{|l|}{$0.17^{\prime \prime}$} \\
\hline Q $\mathrm{T}$ 時間 & $0.42^{\prime \prime}$ & & \multicolumn{2}{|l|}{$0.42^{\prime \prime}$} & \multicolumn{2}{|l|}{$0.44^{\prime \prime}$} \\
\hline 肢 誘 導 & \multicolumn{2}{|c|}{$\begin{array}{l}\mathrm{I}, \mathrm{Q} \text { S 型. S T.上㫧. T逆転 } \\
\text { II III, S T降. } \\
\end{array}$} & \multicolumn{2}{|c|}{$\begin{array}{l}\text { I. Q r 型. S T上昇. T逆転 } \\
\text { II II, } \mathrm{T} \text { 平低 }\end{array}$} & \multicolumn{2}{|c|}{$\begin{array}{l}\text { I, Qr型. S Tやや上昇. T陰性 } \\
\text { III, S Tや低下 }\end{array}$} \\
\hline 单柯肢誘疅 & $\begin{array}{ll}\mathrm{aVL}, & \text { Q S 型 } \\
\mathrm{aVF} & \mathrm{S} \\
\mathrm{S} \text { T俥降 }\end{array}$ & Tやや上昇 & \multicolumn{2}{|l|}{ aVL, $\underset{\text { T逆転 }}{Q}$} & \multicolumn{2}{|c|}{$\mathrm{aVL}, \underset{\mathrm{T} \text { 逆転 }}{\mathrm{Q}} \mathrm{ST}$ 上昇 } \\
\hline 単栖䏨部誘導 & $\begin{array}{l}\mathrm{CR}_{1-4} \\
\mathrm{CR} 5-6\end{array}$ & & $\begin{array}{l}V_{1} \sim V_{4} \\
V_{6} \sim V_{8} \\
\text { 一肋間上: } \\
V_{1} \sim V_{3} \\
V_{4}, 5 \\
V_{6}\end{array}$ & $\begin{array}{l}\mathrm{rS} \text { 型 } \\
\mathrm{T} \text { 逆転 } \\
\text { rS型 } \\
\text { Q S 型 } \\
\text { Qr型. T迹転 }\end{array}$ & $\begin{array}{l}\mathrm{V}_{1} \sim \mathrm{V}_{6} \\
\mathrm{~V}_{1} \sim \mathrm{V}_{3} \\
\mathrm{~V}_{7} \\
\text { 一肋間上 } \\
\mathrm{V}_{4} \sim \mathrm{V}_{6} \quad 6\end{array}$ & $\begin{array}{l}\mathrm{rS} \text { 型 } \\
\mathrm{S} \mathrm{T} \text { 上昇 } \\
\mathrm{S} \mathrm{T} \text { 下降. } \mathrm{T} \text { 平低 } \\
\mathrm{S} \text { 型. } \mathrm{S} \mathrm{T} \text { 上昇 }\end{array}$ \\
\hline
\end{tabular}




\section{写真 2 心 電 図}

29. 10.1 .
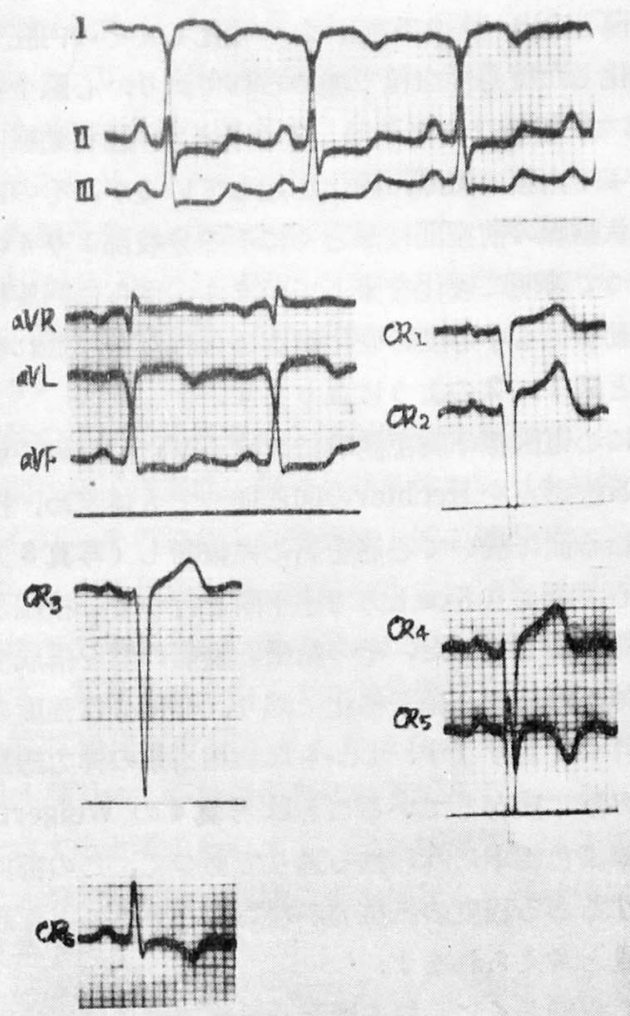
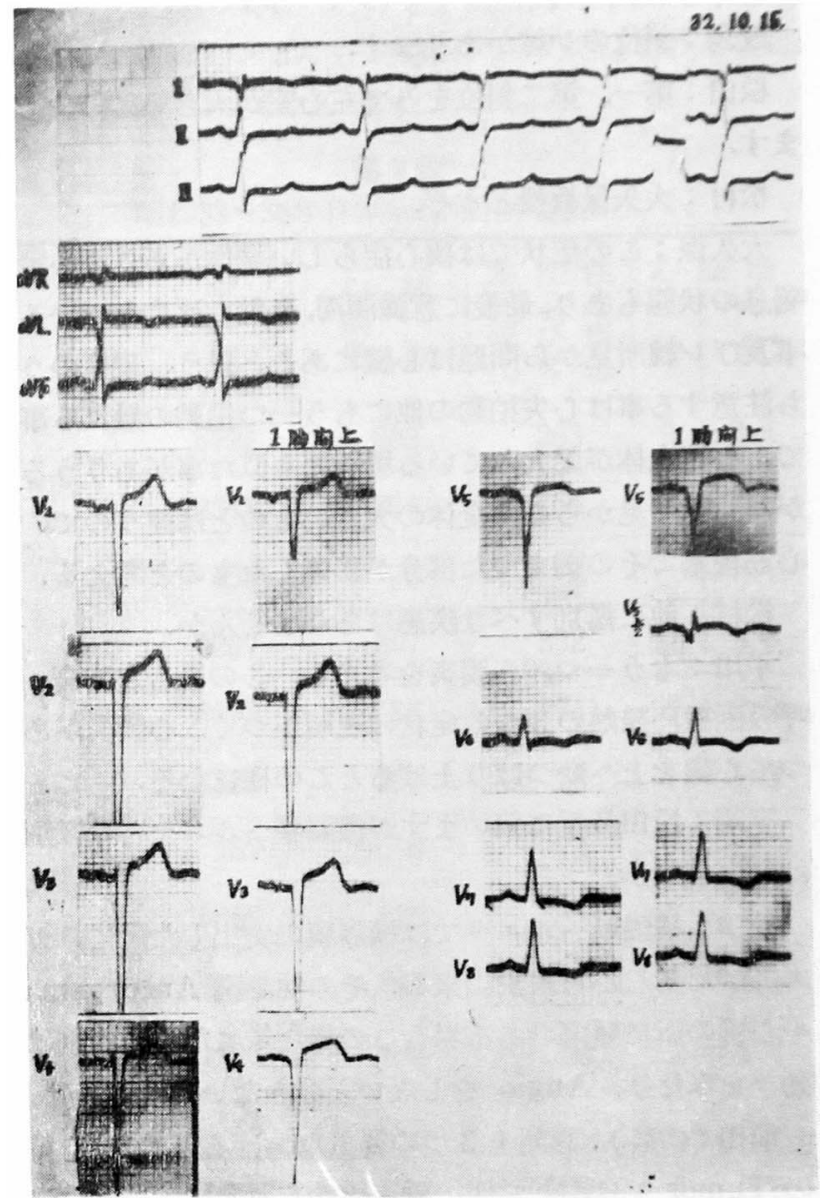

$36.11 .10 \%$

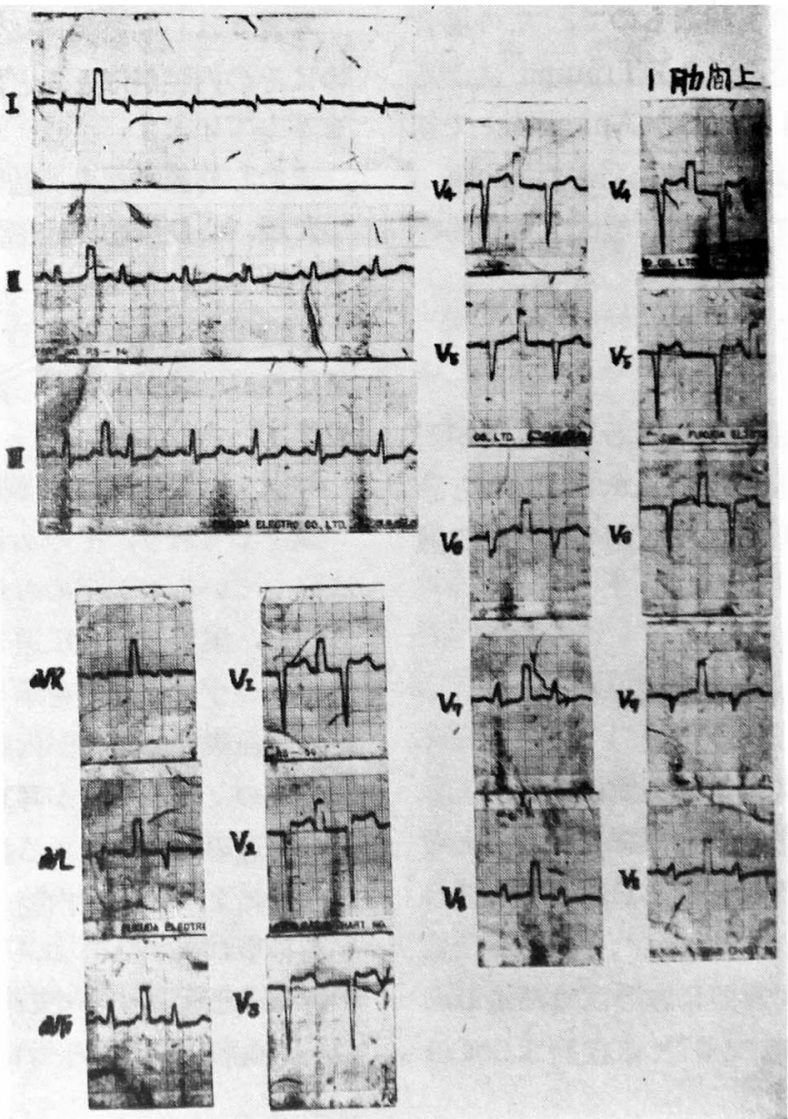




\section{見せて下さい，}

㳇島：斜位のレ線があります。

松田：第一，第二斜位をみて左心室が大きいと結論し ます。

松村：大久保教授どうぞ.

大久保：この症状では狭心症らしい発作があり，心捱 喘息の状態もあり，最後に意識溷濁，発熱で死亡している 事及びレ線所見から問題は心䁍にあると思う．現症のう ち注意方る事は心尖拍動の他にもう一つ拍動の触れる事 で，心觜全体が肥大している場合にる似た事がありうる が, レ線所見から心满全体の大きいむのとは違うので, 心筋梗塞でその弱まつた部分が膨隆したるのと考える。

松村：他に監別すべき疾患はありませんか。

平川：もう一つ，心膜炎を考える。この場合左胸痛， 呼吸困難，発熱の 3 つの症状の説明がつく，心膜炎があ つて心践を上へひつばり上げるとこの様になる.

完岡：松田教授に伺いますが横隔膜へルニヤとの区別 注如何ですか.

松田：横隔膜へルニヤでは横隔膜の突出した所に，ガ ス等がたまるから区別出来る. その他心廐 Aneurysma や心衰の所に腫湯のある場合この様な像になる．区別は 功きをみたり，Angio をしないと分らない。

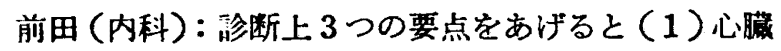
の Tumor で良性と悪性, 更に悪性を原発性, 続発性に 分ける. ウェーレの統計では, 原発性は8500例の内0.05 9, 続発性は0.06\%で，何れも稀なるので, この場合 Tumor を思わせるものはない（2）Trauma による 事むあるが, Anamneseが違う.（3）Anamnese で初 め狭心症の竝断がつけられたが, 最初の発作の長い事, 白血球增多, EKG 所見から心筋梗塞に起因する心笳の 弱まつた事による心贜㨨と考える。

松村：EKGを再度祱明して下さい。

鲛島：説明 (略).

松村：結局病歴 EKG から前壁梗塞があり，心筋が弱 まつて乫出が出来た, 即ち左室前壁の Aneurysmaと湸

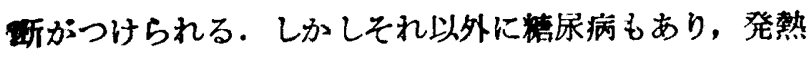
るある.

死亡前の発熟の原因何ですか.

铰岛：最後に気管支肺炎を併発して死亡しました。

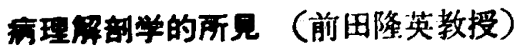

丙理学の立場から本症例に於いて特に意義があると考 えられる心，肺，掔等の䠃器の所見をとりあげて述べる こととします。

ます最る間题の心瞒についてみるに左心室は拡張し， 左心空前塹は心尖部より心底部にかけて直往䄪 $5.5 \mathrm{~cm} の$
半球状の膨隆部が左冠状動脈湔至間枝を左方に代排して いる所見が認められます. そのため㜔隆部の心筋は極度 に菲薄となり (約 $0.5 \mathrm{~cm})$, かつ硬化してその内腔全体は 器質化した壁着性血栓で埋められており, 心眼全重量は $440 \mathrm{~g} て ゙$, 重量はかなり增しております。冠状動脈は企体 に亘って内膜の肥厚, 硬化を起しているが, その内でも 左冠状動脈の前窒間枝がとくにその分岐部より $4 \mathrm{~cm}$ 末梢

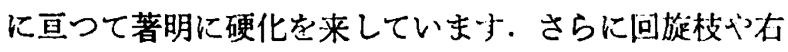
冠状動脈にも中等度の硬化が認められたが，これを図示 すると図1，2のようになります。

次に心電図標準胸部唀導における $\mathrm{V}_{1} \sim \mathrm{V}_{6}$ の心筋上に おける投影点をHechterの図に従つて大体定め，投影点 を連ねる面に於いて心筋を斜めに緥断し（写木3），さ らに心尖端より $5 \mathrm{~cm}$ 上方で水平断を行つて一枚続きの大 切片を作製しました。 その結果心䑏瘤の壁を構成する心 筋全体が瘦痕化，硝子様化に陥り，一部分治強度の石灰 化を伴つております. しかむなお相当量の弾力線維が心 臓瘤の壁に残存していることは写真4の Weigert 氏弾 力線維染色標本にみられる通りであつて, この部に血压 に対するある程度の抵抗力がなお存在することを思わせ る所見と考えられます。

左心室壁とくに心筋の深層や乳嘴筋内には広範囲に亘 つて膯原化ないし般痕化が破められ，大小不同の胼胝栄 が心壁の諸所に散在性に認められたが，これらの听見は 大略図 3 亿よつて示されます.

写事 5 沁心笳胼崏内に於いて内膜が著しく肥厚し，た めにその内腔がほとんど閉鎖されている冠状動脈の細枝 を示しています。

また心筇緃断面の凍結切片に就いてズダンIII染出を行 つたが，心筋脂肪変性部位と心筋胼胝の部位とは必ずし も一致していません.

陠臓：俢出液で充満している肺胞腔内の到るところに 無数の好中球が存在し, 激しい気管枝肺炎の像をふして います。

脪蔵：実質腺組織は菱縮性であり，ラ氏島も萎縮性か つ減少しており，そのあるすの注とえど全体が線維化 に陌つているのが認められます。間質結合組織は增殖が 著明で，実質組織を圧迫しており，結合組織内の小血管 内膜はいずれる肥厚を示し，アザン染色で赤染するが， これは血漿性俢出物が内膜に淁潤している所見と考えら れ，このような所見が写事6によつて示されています。 その附近の間質队にある細動脈のあるものには器質化し た血栓によつてその内腔がほとんと閉塞されている所見 が認められます。

祭贜：まず目につくのは系毢体の硬化像であつて，そ

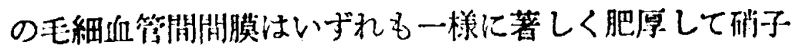


㴍化を示しており，エオジンで均等に淡赫に染つてい ます. その組織化学的性質は PAS 反応陽性であるほふ 注細は判らず,フザン染色，Masson 氏法の Goldner氏 㴶法で緑染, Van Gieson 氏染色では赤染, 銹銀染色を 行うと黑褐色線維状に染まり, 凍結切片ではズダン亚染 任陰性であるが，これらの所見は腎蔵系毢体毛細血管間 破化症の㴊漫型であることを示すもので, 写真 7によつ て亦されます，この際同様に存在する系球体輸出小血管 の硬化，硝子様肥厚像も糖尿病腎に特徵的な所見とみな されをす。

糸毛体の中に洗数視野に 1 個程度ではあるが, 毛細血 倧係蹄間に硝子様変性に陌つた球状体ないし小結節部分 が涊められ，その染色上の特性は上述の涠漫型と巽つて ワンギーソン染色で黄染, 凍結切片におけるズダン亚染 仙は陽性であるが，その他の染色に関してはほぼ一致し ています，军真8はとのアザン染色所見を示しており， 乇細血管間硬化症の 結節型と称されるもので， Kimmelstiel-Wilson が糖尿病腎に特有であるとみなした所 见に一致すると考兄られます。なお細尿管には著変がみ られないが，間質結合組織はやや增殖して浮腫性に扒つ ております。

以上の成緽を取り緾めて病理解剖兴的所见を列挙しま -与と

1. 心臟溜 (左空前壁)，心筇胼胝.

2. 心筋脂肪変性, 心筋褐色萎縮.

3. 冠状動脈硬化症.

4. 毛細血管間系速体硬化症.

5. 两側気管枝肺炎.

6. 膵蔵萎縮, 三民鼠萎縮硬化.

7. 膵臓動脈硬化.

8. 大動脈硬化症.

9. 内分泌蔵器 (副婜, 甲状腺, 案丸等) 洗維.

10. 肝臟萎縮.

11. 脾满菱縮。

12. 線維性瘾着性心外膜炎.

13. 線維性瘾着性肋膜炎.

14. 胸水.

15. 浮腫 (乎足).

16. 䀒臓右葉腺腫 (宪至大) 。

17. 大腸粘膜下脂肪腫.

18. 两側重複輸尿管.

19. 全身栄鉒障害.

以上の通りになります。

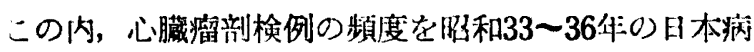
理㳯検諿報に就いてみるに，4年閆の剖検総数42954例中 心臟㨨は39例（内男子31例，女子8 8例)，0.091\%であり，
男子対女子の比は 4：1で,男子に压倒的に多いが,その 此は各年度によつて大きく変動していることは次の表に よつて詳細に示されています。

\section{第3 表}

昭和33～36年日本病理剖娭輯報より。

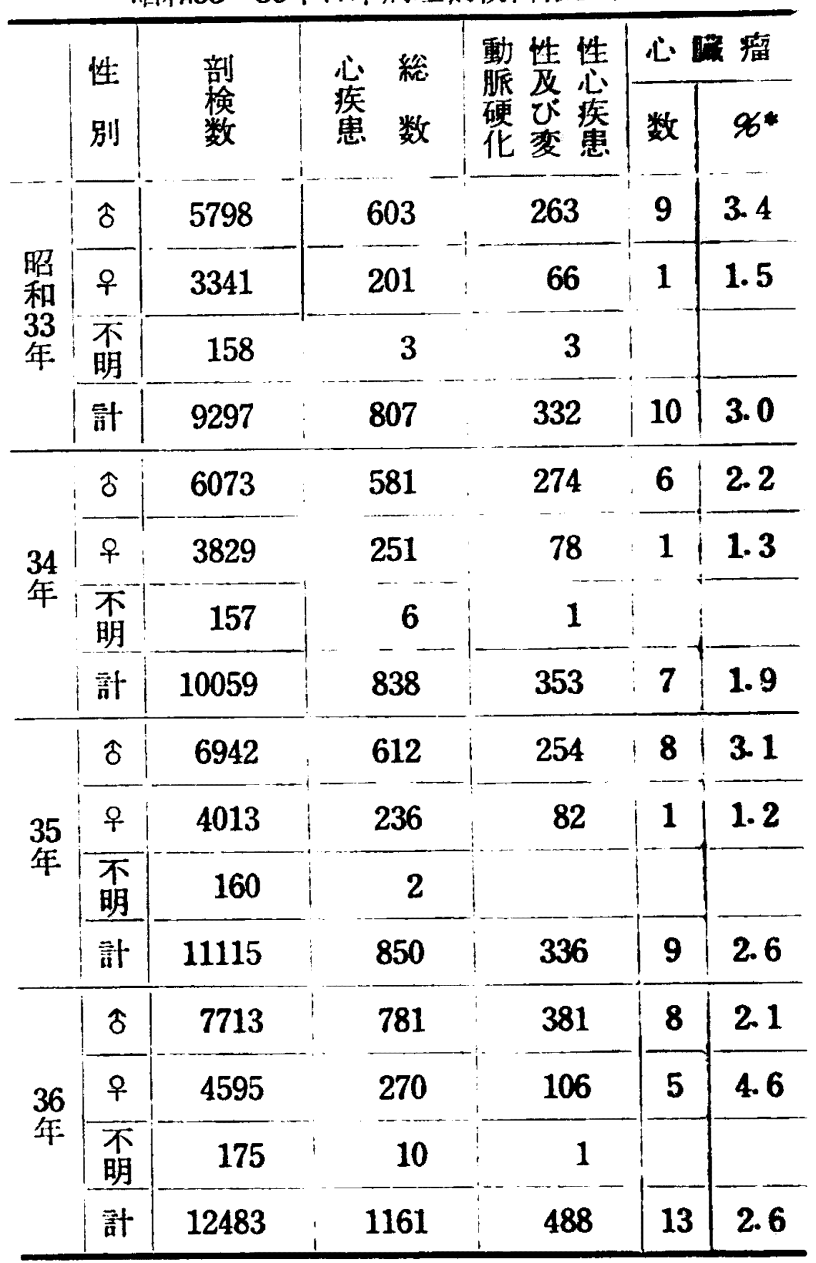

*動脈硬化性並びに変性心疾患に対子る頻度.

欧米の剖検例における心眽渻の発生頻度に就いてみて も，人によりかなりの差異が認められ，Wartman 等は 総数2000例中35例(1.75\%)の心䁍㨨を見出したが，本底 例は65例の梗塞例中に含まれているので，心眼瘭は梗塞 例の 22\%を占めていることになり，このタは欧米におけ る比柬の中でる高い方に属します．他方我国における\% を欧米と比较しますと，例えば昭和36年度における部

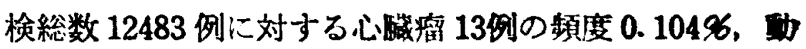

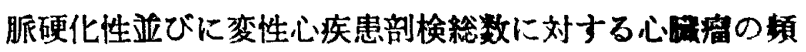
度2.6\%, 昭和33～36年度 4 年間通算全剖検例に対与る心 臓瘤の頻度0.091, 動脈硬化性並びに变性心疾患剖検䋛数 に対する頻度2.58\%はいずれも欧米に比して著しく低く なつています.心䑏瘤自体の大きさに就いては, Caplan 等によ机ば21例の平均直径 2〜 $4 \mathrm{~cm}$, 深さ1.2〜 $3 \mathrm{~cm}$ です

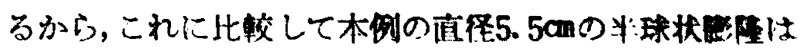


かなり大きい方に原するといえましよう，また本例の心

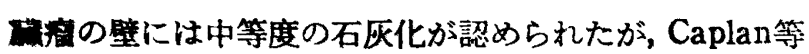
も心溜20例中30\%に石灰化を認めています. Weiss に よれば最近の致死的の心筋梗塞例の約 $5 \%$ は筋の破裂 によるものであり，さらに心瞒破裂例の10\%余りが心蔵 癌破裂によつて占められていることが指摘されていま

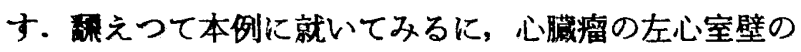
厚さは僅か $0.5 \mathrm{~cm}$ にすぎず，しかもその組織には胼胝， 石戻化が著明であり，正に心䁍破裂一歩手前の状態にあ つたといえるでしょう.

次に心瘤の病因に就いては，一般に冠状動脈の血栓 乃至心筋梗塞に続発すると考えられており，Wartman及 びSaunders は病変が心室壁全層に及ぶに従つて心䁍瘤 が発生する頻度が高まることを見出しています，本例は 冠状動脈硬化症ことに左冠状動脈の前窒間枝の硬化が著 明であり，それに伴つて心筋胼胝が左心室前壁に広範围 に認められたことや, 病巣附近の小動脈の内腔閉塞が検 镜されたことはこれらの所見が心臓瘤の上述の解剖学的 位置と一致して認められることと相俟つて，心蔵瘤の発 生原因を冠状動脈硬化症に求めることができると思いま 于.

次にKimmelstiel-Wilson の所謂 intercapillary glomerulosclerosis 糸毢体毛細血管間硬化症の問題に就い て考えてみるに, KimmelstielおよびWilsoinの報告以来 系毢体における球状ないし結節状硝子様肥厚が糖尿病腎 に特有な所見であるとされており，Kimmelstiel等はつ ニリン青・オランゲG染色法を使用して検索し, intercapillary glomerulosclerosis $は$ 系毪体毛細血管閒結合 組織の増殖に基くとみなしました. この後 Allen, Mc Manus, Randerath等は本例に於いて試みた様な組織学 的並びに組織化学的染色法を行つて intercapillary glomerulosclerosis の染色上の諸種の特性を見出してい ます.この内 Allenは, 本所見のみならず本例にす認めら れる陯出血管壁の肥厚をむ糖尿病に特徵的な所見である とみなし稐出血管壁の肥厚を絿体内压上昇の原因と考 え，またintercapillary glomerulosclerosisの発生に関 して,これはむしろ毛細血管壁自体の硝子様肥厚に基く と考えたが, McManusはその後 PAS 反㐫を行つてみて これを否定し，Kimmelstiel等の見解を支持しました. Randerath：は球状硝子样肥厚を重症糖尿病例にみられ るというズダン染色险性，ワンギーソン染色で赤染する るのと柽症绾疗病例にみられるというズダン染色陵性, ワンキーンン染色で黄染する二種類を区別しているが, 本例で認めたるのは後者に属します， intercapillary glomerulosclerosisの地現頻度に就いては, Kimmelstiel
等によれば糖尿病例の $17.1 \%$ であり，系毯体係政の硐漫 性硝子様肥厚即ち洞漫型を算入するとその出現頻度は著 しく高くなるが，糖尿病に対する特異性は著しく低下寸 ると考えられます.Goodof は intercapillary glomeru一 losclerosis は糖尿病例の44\%にみられると述べ，こと にその高度の病変は糖尿病患者のみにみられるとしてい るが, Zins むこれとほぼ同様な成績を得ています。本例 に於いては球状硝子様肥厚は数視野に辛うじて 1 個を認 めた程度でありこれに対して洞漫型は糸毢体数個に 1 個程度という比較的高率に見出された。球状ないし結節 状硝子様肥厚の発生機転に就いては，糸正体毛細血管係 蹄のある部分に壁の肥厚等に基く㹟窄が生じ，その下流 にあたる部分は血獎のみが流れ得るに過ぎなくなり，そ

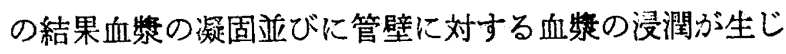
て，これが血獎内の脂肪成分と共に硝子様化に陥り，す でに起りつつある毛細血管間結合組織の硝子様肥厚と痹 合して, 結局このものが結節状ないし球状硝子様肥厚と して認められるに至るものと考えられます.

intercapillary glomerulosclerosis は,また糖尿病が 長期間に亘る程出現率が高いとされ，症状の軽重よりは その持続期間が出現率に影響があると考えられていま す. Zinsはintercapillary glomerulosclerosisの高度な むのは中等度の糖㽷病患者に見出されるものであつて, 重症糖疗病患者には反つてみられず，また霍病期間15年 以上の糖尿病例の全部に見出されると述べ, Goodof も18 年以上に亘る糖尿病患者全例に本所見が認められると述 べています.この点本例は糖尿病の䍜病期間が30年にも 亘つていると考えられるので, intercapillary glomerulosclerosis の出現は当然であるといえましょう.なお intercapillary glomerulosclerosis 出現の予後汢一般 に不良とされており，本所見出現に伴つて蛋白尿，浮腫 等の腎蔵機能障碍へ高血圧症状がしばしば起るとされて おう，それらの症状発現後数年以内に尿毒症あるいは心 臟機能障碍 (この方の頻度が多いとされている) 等でほ とんど死亡するといわれています。.

本例は主に自宅療養であつたため症状の部細は判明し ない感みはあるが，昭和 35 年 3 月頃即ち死亡 2 年余り前 : : は中等度の高血糖, 尿糖が存在していたことは恰查の 絬果判明しています. 以後この症状が一進一退していた ものとみなされ，残余窒素の上昇も比較的軽度にすぎず， 剖倹でも尿毒症を思わせる所見はほとんど喍められなか つたので, intercapillary glomerulosclerosis が本例 の死因に直接関与しているとは考元難い。心臟瘤に就い ても本例では心臓溜のみならず冠状動脈硬化症ないし心 筋梗塞に基くと考えられる心臟機能不全のはつきりした 
ものは認められていません. 他方重篤な気管枝肺炎像が 見出されており，かつ心，肝，膵，脾等の実質臟器並びに 内分泌臓器の萎縮が著明に認められるので, 結局本例は :臟器萎縮を伴う全身衰弱が存在していたところに気管枝 肺炎が偶発的に䓯起して，これが直接死因となつたもの であり，その背景に糖尿病显びに毛細血管間系粊体硬化 症や巨大な心臟瘤等が存在していたと考光られます。

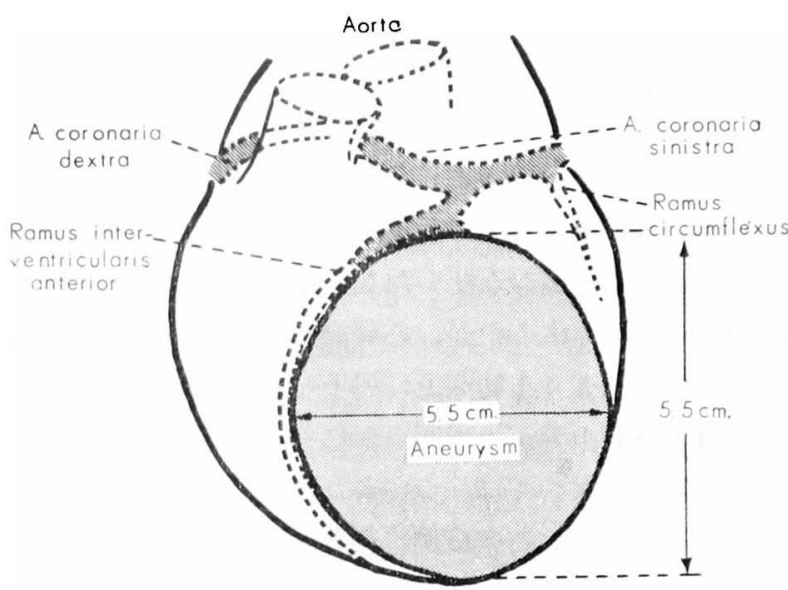

图 1 （前面）

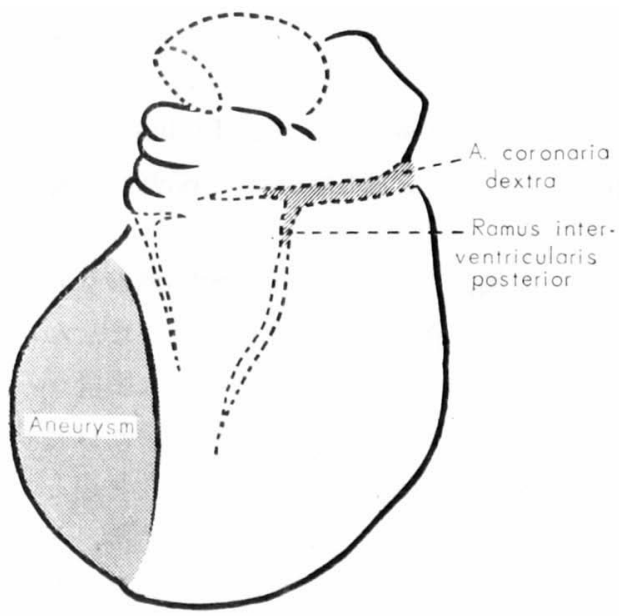

図 2 (後面)

註：斜線の部分は硬化部位を示す。

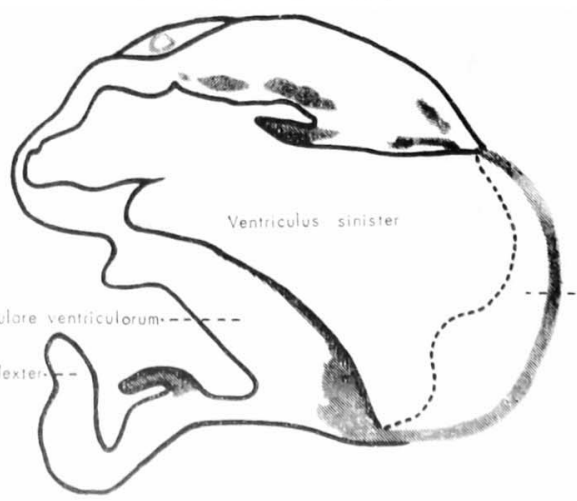

図 3

註：斜線の部分は心筋内胼胝巣を示す。
総括

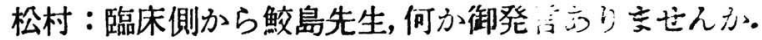

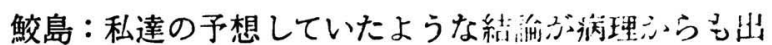
さされました。それで本疾患を文献的に考察したい之思い ます。心臟瘤は1757年 Galeati, Hunter こよつて初放て 記載されました，発生原因としては本例のような冠動脈 閉塞が最も多く, 稀に細菌性心内膜炎, 結核, 外傷文ど による報告があります.一般に冠閉塞の発作後 1〜2 㴡

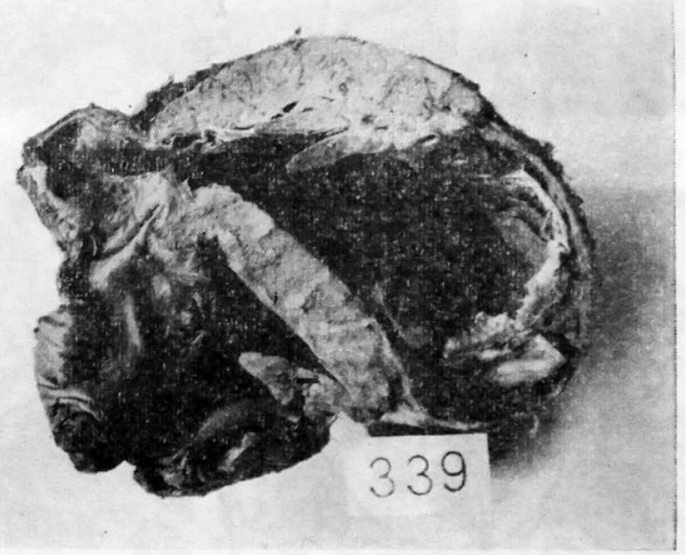

写真 3

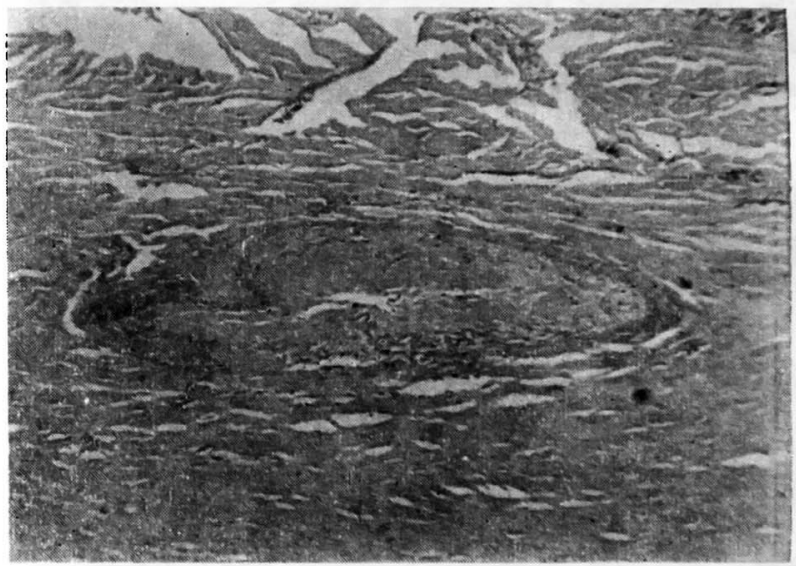

写 真 4

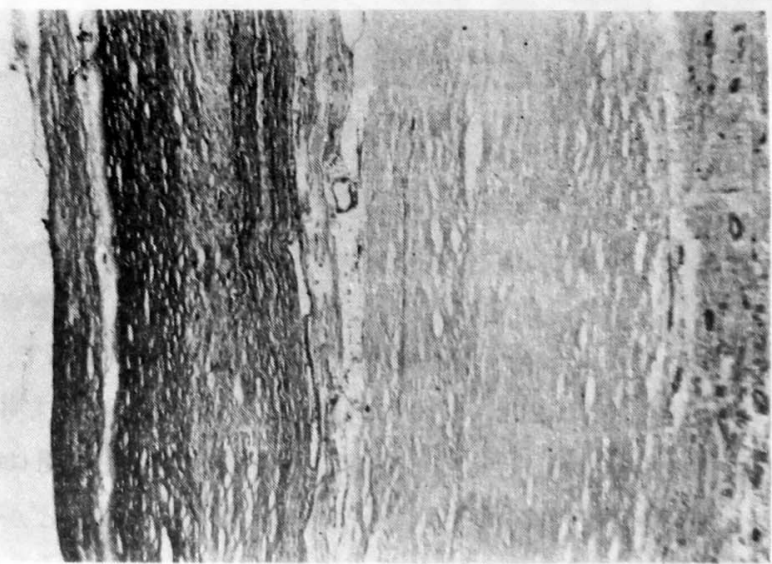

写真 5 


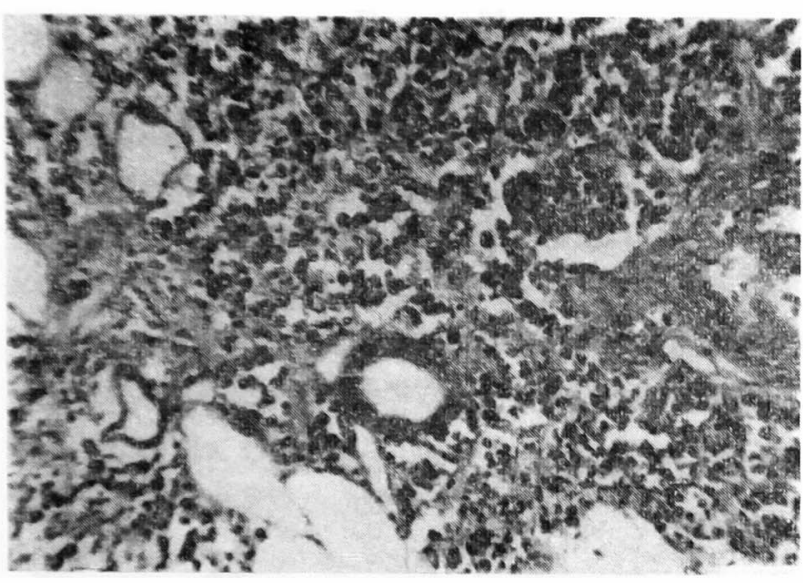

写真 6

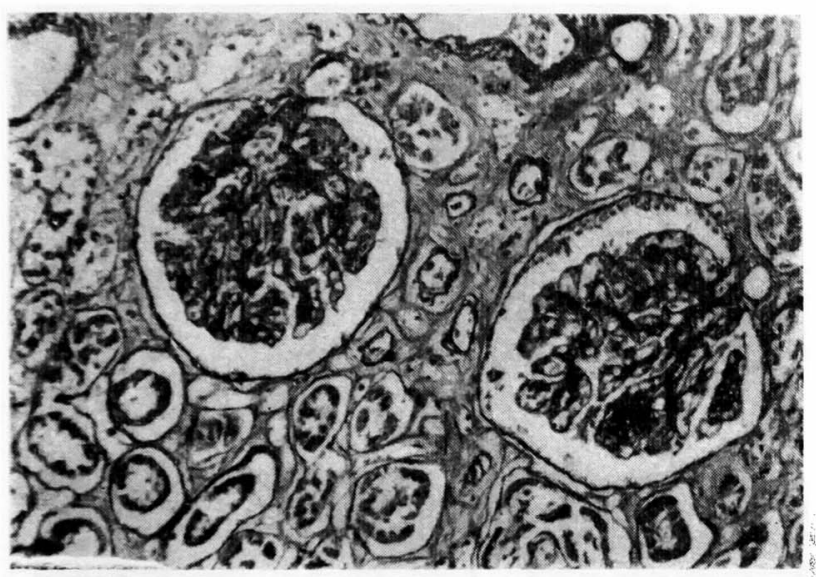

写 真 7

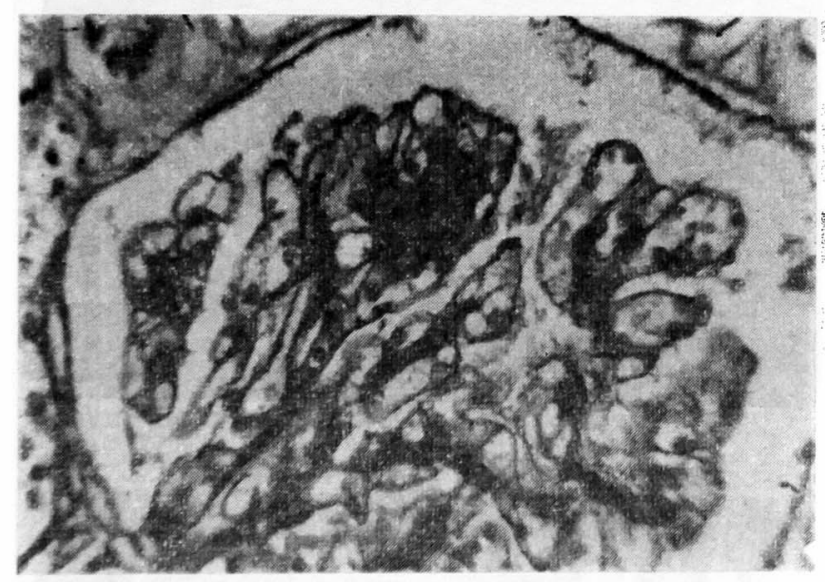

写真 8

「ii, Parkinsonらは17カ月後に発生したものを報告して

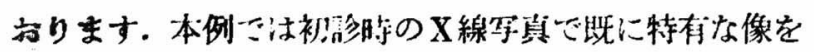
みておりますから，14月以内之考えられます，心筋梗塞 後本定の発生頪度は, Betsch $8 \%$, Lisa ら 5 〜38\%で, 多くの般告穵みすすと大体10\%前後であり，性別では男 チに特に多い上うです．心搰㨨の大きさ淔径 $1 \sim 8 \mathrm{~cm}$ 大大16cmというものもございす. 発生部位は殆えどが 左室，殊に前壁心尖部に多く，後壁基底部のものもみら

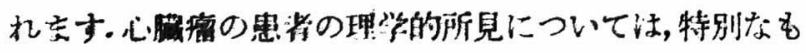

のはないとされておりま少が，本例にみられましたよう な心尖部と胸骨の間の異常拍動, あるい: murmurなどの記載がございます．1傥症状も特殊なも のはございません，X線像は左心の不釣合な拡大，皤壁 に沈着した不灰除影, キモグラフィーによる所見, 透視 では心臟瘤部の拍動が非同時性のことなどが埍載されて 将り末す。本例では膨隆部の拍動が: 心尖拍動と一致せ ず,やや逢延し，X線の 2 重撮影で膨隆部が他の心室部. に比して収縮期, 抬张期の差の方しい浙見がえられまし た。心電因所見は仵々の報告がございますが，前壁瘤で は低いR I, 深い S IIII, 陰性の T I, aVL, 胸部誘 導の $\mathrm{Q}, \mathrm{ST}$ 上星どいた前壁梗寒の所見があげられま

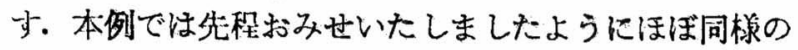

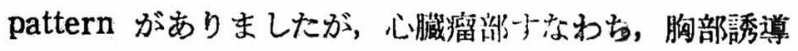
で所定の場所より1肋間上に学子を将いて撮影いたしま 寸とQと ST 上昇が一層明らかにみられましたので，心 藏溜の場所によつては，このようなことも試してみるべ きかと存じま尗。この症例は約 8 年閒にわたり経過をみ ましたが，その閒心電図の基本的な所見は殆んど変化し ておりません。 それで, 私は infarction pattern がい

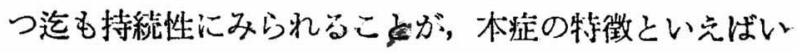
えるのではないかと考元て打ります，生前に本症を祅断 することはかなり困難なようで, Fisher は不可能であ

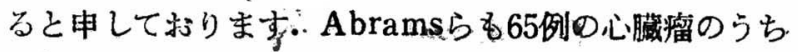
4 例しか生前に酸断をつけておりませんし，本邦でも心 臟晐として症例報告されている症例25例のうち，生前に 禞断されたのは本例を会めて2例にすぎませ．この症 例のように背腹方向のX線写真で特有な膨隆がみられる ものは，この疾患を知つてさえ执れば晹断は容易ででざ いますが，X線の側面，斜位撮影などを併用しても発見 が困難なものがございます.一般に心電図, X線, 心臓 の理学的所見では, 本症にこ机という特徴はないといわ れて抢りますが，先程申し述べましたような所見が診断 のたすけになると思います。，その他，梗塞発作の既往 歴, 梗塞発生後の安静状態之か, 本例も糖尿病患者であ りましたが，Abramsらは65 例中24例が糖尿病であつ たと申して抢りますから，こすいうことも少しは参考に なるかと存じます. 予後は Schlichter の報告では症例 の35\%が血栓栓塞症をおこし，うち21.7\%がそのために 死亡, また70\%がうつ血性心不全に陌り，48.1\%がそれ で死亡して抢ります。臓瘤の壁は極めてうすくなつて おりますわりに，心眼破裂は案外少く，Gross らは43 例中皆無, Abrams らの65例には3例にみられたのみ でございます。この Abrams らの報告では，23例が 気管支肺炎あるいは尿毒症との他で死ししています。 大体心蔵瘁ができてから 5 年以内に $88 \%$ 多亡するよう 
でございます.が, Master らは29年間社会活動をした

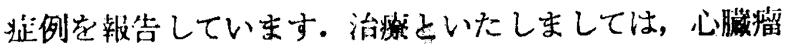
㰾の切除が行われ，かなりよい成績を納めております。

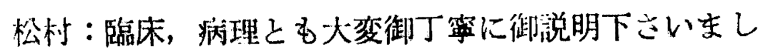
たので皆様よく御了解下さつたことと思います。本のの CPC は隐休病理とむに沴断が極めて明確なので, CPC として注興啉がありますが，“なぞとき”としては面白 く次かたかも知れません。淮か陵休の先生方で病理の 涚明:刘し御質ねがありませんか。ななれば私から御 質称したいことがあります。前田教授は Kimmelstiel一 Wilson のあることを指摘しておられますが，本症は高 血压が一次性にあり，それに統いて糖尿病が併発したも

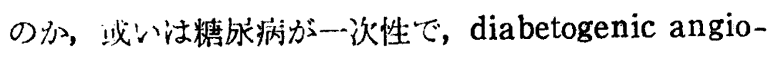
pathyの一つとして心臟瘤が発生したと御考えですか.

前田：糖尿病が長い間ありそとてて腎に Kimmelstiel一 Wilson 氏症候の所見のほか 絿体毛細血管係蹄の壁内 にアザン染他で赤染する血洯俢出物がしばしば恩められ また膵臓の小動脈に洞栏の所見が見出されたのみなら ず，そのしかむ腈の小動脈には著明な硬化像や器質化し た血栓によつてその内腔がほとんど閉塞されている所見 も涊められました。このような所見は，糖尿病が持続し

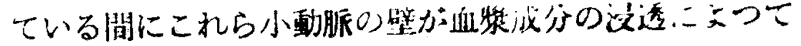
潮次障碍されて, 結局硝子様化に陷一て硬化像を萑起す るに至つたものと考えることができすよ。その結果，局

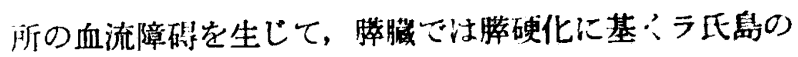

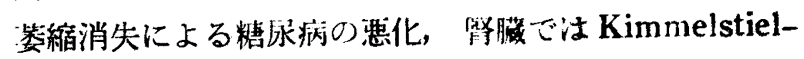
Wilson 氏症候の增要が独らされることが推定こきます。 このような条件下で注高血圧や゙それに続く冠状動脈硬化 の発症も容易に考えられるから，本症例ては diabetogenic arteriosclerosis の機軘汸行われていたこ考えて 宜ろしかろうと思います。

魰島：臨床でも本例は糖尿病による冠動脈硬化症か;， 心筋梗塞を扢こし, 心臟㨨に発展したものと考云, 治痖 していました。

松村：最後に前田教授に一・山打牌します。

前田（内科）：かつて Gross u. Guleke が脺硪炎の 沴断は膵臓のある事を知つている事から始まるといつ た.これと同じく Herzに Aneurysma のあろ事を知 つていることが Herz aneurysma の診断をつける始め であるとつけ加えたい.

松村 : 皆様の御協力でうまく結論に年しましさので終 りたいと思います. 